IVICA ČREPINKO

Libertas međunarodno sveučilište, Zagreb

icrepinko@gmail.com

DINKO PRIMORAC

Sveučilište Sjever, Koprivnica

dprimorac@unin.com

GORAN KOZINA

Sveučilište Sjever, Koprivnica

gkozina@unin.com
Primljeno: 10. 11. 2020.

Prihvaćeno: 25. 02. 2021. DOI: $10.21857 /$ yrvgqteol9

\title{
ANALIZA POSLOVNIH PROBLEMA MALIH I NEOVISNIH TRGOVACA U VARAŽDINSKOJ ŽUPANIJI
}

Ovaj rad istražuje analizu poslovnih problema malih i neovisnih trgovaca, njihov utjecaj na razvoj gospodarstva sjeverozapadne Hrvatske, a posebno Varaždinske županije. Budući da mali i neovisni trgovci imaju iznimnu važnost za trgovinu sjeverozapadne Hrvatske kroz ovaj rad želi se prikazati njihov utjecaj na određene čimbenike u gospodarstvu, te sintetizirati osnovne probleme koji utječu na njihov razvoj. Kroz empirijsko istraživanje u radu se utvrđuju prednosti i slabosti neovisnih trgovaca, te važnosti potrebe za njihovim dobrim pozicioniranjem na tržištu, ali i boljim povezivanjem sa stalnim i potencijalnim potrošačima.

Ključne riječi: maloprodaja; Varaždinska županija; mali neovisni trgovci. 


\section{UVOD}

Trgovina predstavlja jednu od najstarijih gospodarskih aktivnosti i prisutna je u ljudskim životima od samih početaka razvoja civilizacije. Prvi put se pojavljuje 4 tisuće godine prije Krista u vrijeme sumerske civilizacije. Od navedenog vremena pa sve do modernog doba trgovina se neprestano razvija i prilagođava uvjetima tržišta. Svoj ubrzani razvoj trgovina je doživjela u drugoj polovici 19. stoljeća. Sami proces trgovine može se definirati kao vještina ili skup pravila po kojima se legitimne osobe pravedno vladaju u trgovačkim stvarima radi očuvanja ljudskog roda, ali ne manje $s$ nadom u dobitak. ${ }^{1}$ Huška navodi kako je trgovina gospodarska djelatnost u kojoj pojedinci i tvrtke posreduju između proizvodnje i potrošnje kao kupci i prodavatelji dobara usluga te organizatori tržišta - osnovni cilj ovakve razmjene dobara i usluga je zarada, odnosno profit za trgovca te zadovoljenje potrebe kupca. ${ }^{2}$ Međutim, pojam maloprodaje potrebno je razlikovati od pojma trgovine, budući da ovaj pojam podrazumijeva samo prodaju na malo. Maloprodaja označava samo onaj dio trgovine koji se odnosi na prodaju na malo, a maloprodajno poduzeće može imati nabavu istodobno organiziranu i za trgovinu na veliko.

$\mathrm{U}$ današnjem modernom svijetu, u kojemu je čovjekovo efikasno upravljanje vremenom jedno od ključnih životnih ciljeva, mali i neovisni trgovci se često svrstavaju u drugi plan, tj. smatraju se „manje važnima“. Naime, ono što kupce privlači u sve veće trgovačke centre, kako bi na jednom mjestu imali ponudu što većeg asortimana proizvoda i usluga, mali nezavisni trgovci jednostavno ne mogu pružiti. Nadalje, ulaskom novih međunarodnih trgovačkih lanaca na hrvatsko tržište, te daljnjim akvizicijama i/ili spajanjima domaćih trgovačkih lanaca, mali i neovisni trgovci vrlo često gube svoju vidljivost i prepoznatljivost na tržištu. ${ }^{4}$ Istina je da se malim i neovisnim trgovcima vrlo teško boriti s velikim i jakim trgovačkim lancima, s jeftinim stranim izvorima financiranja, s dampingom cijena itd., pa se komparacija njih „velikih i malih" kao konkurentima zvuči neumjesno i jalovo. Međutim, njihova usporedba svakako može poslužiti malim i neovisnim trgovcima kao orijentir za nove načine promišljanja s ciljem opstanka i razvoja. Naime, i mali bi po uzoru

1 BUTIGAN, N. (2017). "Strateški savezi u trgovini na malo u Europskoj Uniji i zemljama Središnje i Istočne Europe", Ekonomska misao i praksa, No. 2, str. 715-746.

2 HUŠKA, D. (2017). "Utjecaj globalizacije na području trgovine na malo u Hrvatskoj 1997-2016.", Zbornik sveučilišta Libertas, Vol. 1-2 No. 1-2, str. 125-136.

3 SEGETLIJA, Z., LAMZA-MARONIĆ, M. (1999). Strategija maloprodaje. Sveučilište Josipa Jurja Strossmayera u Osijeku, Osijek, str. 19.

4 ANIĆ, I. D. (2021). Sektorske analize: Trgovina na malo, Ekonomski institut Zagreb, Zagreb, razrada autora. 
na velike trgovce, trebali težiti pronalaženju inovativnih modela za pridobivanje kupaca kao i stvaranju profita. Tržišta očito postaju sve kompleksnija i sofisticiranija. Perkov napominje kako mala trgovina mora pridobiti i zadržati potrošača, kontinuirano raditi na dodatnoj edukaciji, pronaći nove, male tržišne niše u kojima može biti konkurentna te ponuditi drugačiji asortiman od onog koji nude veliki trgovci. Misija im je otežana i zato što kupuju od veletrgovaca pa su rješenja u zajedništvu. ${ }^{5}$

Specifični interes istraživanja ovoga rada je područje Varaždinske županije koja se sastoji od 6 gradova i 22 općine smještene na sjeverozapadu Republike Hrvatske. Gospodarski spada u razvijenije županije s posebno razvijenim gospodarskim granama tekstilne industrije, prehrambene industrije, drvne industrije, i ljevaonica, a temelj gospodarstva Varaždinske županije čini prerađivačka industrija. Nadalje, na području Varaždinske županije postoje i djeluju dva udruženja malih trgovaca, a to su Udruga trgovaca Međimurje s 22 člana i Udruga trgovaca Sjever Plus s 14 članova odnosno pravnih subjekata registriranih za trgovinu na malo. Uzimajući u obzir da spomenuti pravni subjekti prosječno posluju s dva prodajna mjesta koja zapošljavaju prosječno tri zaposlenika dolazimo do brojke od 216 zaposlenih u navedenim pravnim subjektima što odgovara klasifikaciji srednjeg subjekta malog poduzetništva.

Ovaj rad kroz analizu empirijskog istraživanja daje veliki doprinos široj akademskoj znanosti u shvaćanju važnosti poslovanja malih i neovisnih trgovaca, te njihovoj važnosti kao čimbeniku gospodarskog razvoja Sjeverozapadne Hrvatske. Prikazano istraživanja uvelike nadopunjuje shvaćanja uloge različitih udruženja na poslovanje malih i neovisnih trgovaca, te doprinosu udruženja u isticanju važnosti potrebe za dobrim pozicioniranjem na tržištu, boljim povezivanjem sa stalnim, ali i potencijalnim potrošačima. Analizom malih neovisnih trgovaca prikazuju se specifične potrebe njihovih pojedinih segmenata poslovanja, ali i njihov potencijal. Provedeno istraživanje nedvojbeno daje malim i neovisnim trgovcima određene smjernice za razvijanje svojeg poslovanja prilikom kreiranja poslovnih strategija. U nastavku rada se prikazuju važnosti malih i neovisnih trgovaca Varaždinske županije, analiza provedenog istraživanja, te zaključak.

PERKOV, D. (2010). "Hrvatski mali trgovci danas-sutra". Progressive Magazin 2, str. 18 - 19. 


\section{MALI I NEOVISNI TRGOVCI VARAŽDINSKE ŽUPANIJE}

U Republici Hrvatskoj sve županije svojim gospodarskim aktivnostima izravno utječu na ekonomski i gospodarski razvoj države, odnosno financijski rezultat svake županije zasebno utječe na ukupna ekonomska kretanja. Međutim, svaka županija razlikuje se od ostalih prema svojem teritorijalnom položaju, ekonomskoj strukturi gospodarstva, te gospodarskoj razvijenosti same županije, čime su i sami financijski pokazatelji uspješnosti poslovanja različiti između samih županija.

Kada se promatra Varaždinska županija, te njezina struktura gospodarskih akvnosti vidljivo je da sama trgovina ima značajan udio. Također, promatrajući male nezavisne trgovce, u odnosu na gospodarski sektor trgovine unutar Varaždinske županije, vidljiva je velika važnost udruga malih trgovaca. ${ }^{6}$ Naime, članstvo u udrugama malim trgovcima pruža razne pomoći, informiranje o pravnim okvirima poslovanja, savjetovanja kod poreznih i inspekcijskih službi, nabavu roba u većim količinama za postizanje boljih uvjeta prodaje, dogovaranje boljih uvjeta kupnje i plaćanja kod raznih dobavljača i pružatelja usluga čime dugoročno mali trgovci postižu financijsku stabilnost poslovanja i predstavljaju poželjnog poslodavca u gospodarskom sektoru trgovine u Varaždinskoj županiji. Prema Pravilniku Udruge malih trgovaca Međimurje, glavni zadaci Udruge su idući: redovito informiranje člana o cijenama proizvoda i usluga, dogovaranje i ugovaranje boljih uvjeta nabave, kupnje i plaćanja robe kao dobavljača i pružatelja usluga, organiziranje seminara i savjetovanja kod poreznih i inspekcijskih službi, nabava robe u većim količinama za postizanje boljih uvjeta prodaje, pružanje pomoći članovima u svim momentima ukoliko član zatraži, a udruga ima saznanja o tome, organiziranje zajedničkih druženja - izleta u poslovnom i zabavnom smislu.

Mali trgovci, kao gospodarski stabilni pravni subjekti predstavljaju značajnog poslodavca u Varaždinskoj županiji, te prema Državnom zavodu za statistiku od ukupno registriranih 7.985 pravnih subjekata u Varaždinskoj županiji 1.397 registrirano je za trgovinu na veliko i malo.

U prethodnim godinama, tj. od ulaska Hrvatske u EU, u Varaždinskoj županiji događa se jedan paradoksalan problem kojeg nije bilo moguće ni zamisliti početkom prošlog desetljeća. Naime, registrirana nezaposlenost, prema podacima $\mathrm{Hr}$ vatskog zavoda za zapošljavanje, u Varaždinskoj županiji ima stalan trend pada. U 2004. godini iznosila je 3,36\% da bi se tijekom godina smanjivala sve do 1,96\% u 2020. godini. Predmetni podaci upravo ukazuju na problem zapošljavanja kao

https://www.hgk.hr/zupanijska-komora-varazdin, lipanj 2020. godine.

7 Udruga malih trgovaca Međimurje. dostupno na: https://www.jatrgovac.com/tag/udruga-trgovaca-medimurja, lipanj 2020. godine. 
glavnog ograničavajućeg faktora rasta i širenja novih prodajnih objekata malih trgovaca u Varaždinskoj županiji. Iz susjednih zemalja stiže nova "prijetnja" poslovanju malih trgovaca. Ista se očituje u potrebi radne snage u susjednoj Austriji koja je sa 01.07.2020. godine bezuvjetno otvorila svoje granice za radnu snagu iz Hrvatske, veće primanja i uređenija država sigurno će stvoriti nove izazove za male neovisne trgovce Varaždinske županije u budućnosti, te dodatno onemogućiti daljnji razvoj i širenje malih neovisnih trgovaca poglavito u ruralnim sredinama Varaždinske županije.

\section{ANALIZA PROVEDENOG ISTRAŽIVANJA}

Kroz analizu prethodnih istraživanja malih i neovisnih trgovaca dolazi se do zaključka kako je navedena tema uvelike zanimljiva akademskoj i stručnoj zajednici. Naime, kroz provedenu analizu prethodnih istraživanja pronalazimo domaća istraživanja i analize koje su nas detaljno usmjerile $k$ istraživanju provedenom $u$ ovome radu. Perkov, kroz dugogodišnju analizu malih trgovaca u Republici Hrvatskoj, prikazuje nove trendove u njihovoj zastupljenosti u gospodarstvu. ${ }^{8}$ Knego i Vouk istražuju prednosti i nedostatke malih i neovisnih trgovaca, te daju pojedina objašnjenja za formiranje njihovih strategija. ${ }^{9}$ Hruška se pak fokusira na utjecaj globalizacije na trgovinu u Hrvatskoj. ${ }^{10}$ Segetlija istražuje male i neovisne trgovce kroz utjecaj maloprodajnih strategija na njihovo poslovanje. ${ }^{11}$ Nadalje, eminentne hrvatske institucije kontinuirano objavljuju analize raznovrsnih aspekata male i neovisne trgovine u Republici Hrvatskoj. Tako Ekonomski institut Zagreb kroz Sektorske analize prikazuje ažurirane podatke ${ }^{12}$ ili pak bilteni Hrvatske gospodarske komore koji nam omogućuju detaljan uvid u mnogobrojne aspekte male trgovine.

Sve navedeno motiviralo nas je, da uz dostupne podatke, dodatno analiziramo specifično područje Sjeverozapadne Hrvatske kroz razvoj malih i srednjih trgovaca. Za izradu ovog istraživačkog rada korišteni su primarni podaci empirijskog istraživanja provedenog putem internetske ankete. Primarno istraživanje je obavljeno

PERKOV, D. (2010). "Hrvatski mali trgovci danas-sutra", Progressive Magazin 2.

9 NEGO, N., PETLJAK, K., VOUK, R. (2014). "Location and layout as sources of competitive advantage of small retailers", Economy \& Business Journal, International Scientific Publications, Bulgaria, vol. 8(1), pages 267-281.

10 HUŠKA, D. (2017). "Utjecaj globalizacije na području trgovine na malo u Hrvatskoj 1997-2016.", Zbornik sveučilišta Libertas, Vol. 1-2 No. 1-2, str. 125-136.

11 SEGETLIJA, Z., LAMZA-MARONIĆ, M. (1999). Strategija maloprodaje. Sveučilište Josipa Jurja Stross-mayera u Osijeku, Osijek.

12 https://www.eizg.hr/novi-broj-sektorskih-analiza-bioekonomija-5548/5548. 
putem survey-a servisa za provođenje online istraživanja tijekom svibnja i lipnja 2020. godine. Anketa je dizajnirana u skladu sa postavljenim ciljevima rada i sadrži pitanja o poslovanju malih neovisnih trgovaca Varaždinske županije. Ispitanici su određeni uz pomoć županijske organizacije Hrvatske gospodarske komore, a svim ispitanicima pojašnjena je svrha, cilj i anonimnost istraživanja. U istraživanju je distribuirano 60 anketnih upitnika, od čega je popunjeno njih 38. Dobiveni uzorak je prigodan; obuhvaća oba spola, različite dobi te različit završni stupanj obrazovanja. Pitanja u upitniku ankete nudila su od dva do četiri odgovora. ${ }^{13}$

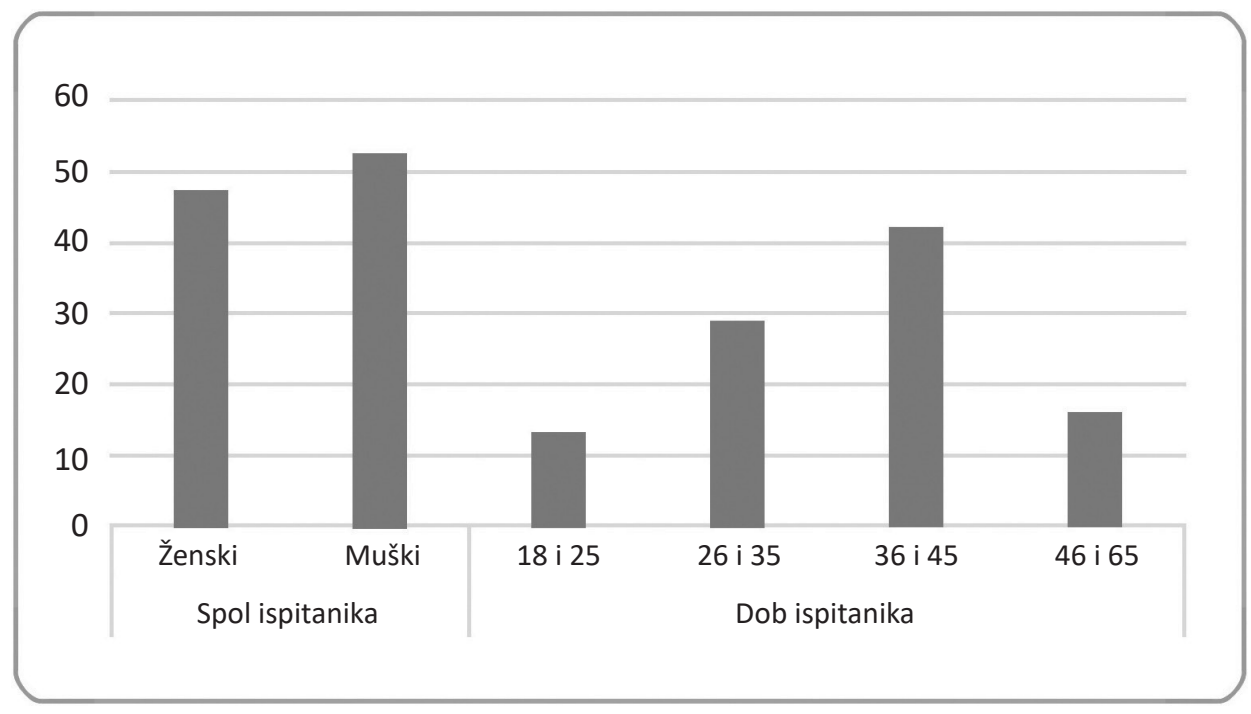

Grafikon 1. Spol i dob ispitanika, Izvor: istraživanje autora rada

Prema rezultatima istraživanja od ukupno $52,60 \%$ je ženskog spola, a $47,40 \%$ je muškog spola. Najveći broj ispitanika pripada dobnoj skupini između 36 i 45 godina; njih (42,10\%), zatim slijedi dobna skupina ispitanika između 26 i 35 godina $(28,90 \%)$, te dobne skupine ispitanika između 46 i 65 godina $(15,80 \%)$ i između 18 i 25 godina (13,20\% ). Iz Grafikona 1 možemo zaključiti da u ukupnom broju ispitanika prevladava muški spol $(52,60 \%)$, te da je najveći broj ispitanika dobne starosti $36-45$ godina $(42,10 \%)$.

13 ČREPINKO, I., Utjecaj malih neovisnih trgovaca na razvoj gospodarstva Sjeverozapadne Hrvatske, (2020) Libertas međunarodno sveučilište, Zagreb, obrada istraživanja autora. 


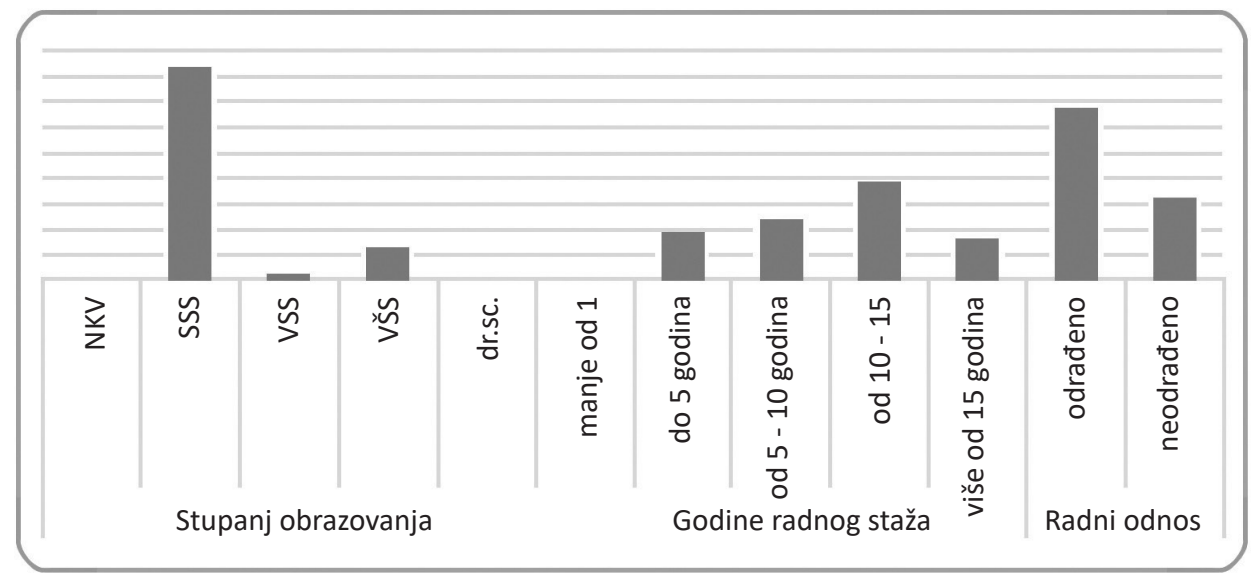

Grafikon 2. Opći podaci o ispitanicima, Izvor: istraživanje autora rada

Rezultati istraživanja pokazuju kako je najveći broj ispitanika sa srednjom stručnom spremom $(84,00 \%)$, slijede ispitanici sa višom stručnom spremom $(13,00 \%)$, te zatim ispitanici sa visokom stručnom spremom $(3,00 \%)$. Nadalje iz Grafikona 2 vidi se da najveći broj ispitanika prema ukupnom radnom stažu pripada skupini od 10 do 15 godina radnog staža (39,50\%), zatim slijedi skupina od 5 do 10 godina radnog staža $(24,20 \%)$, te skupine od 5 do 10 godina radnog staža $(19,30 \%)$ i više od 15 godina staža $(17,00 \%)$. Također, vidljivo je kako veći dio ispitanika s poslodavcem ima sklopljen ugovor o radu na određeno radno vrijeme $(67,30 \%)$ te manji dio zaposlenika koji ima sklopljen ugovor o radu s poslodavcem na neodređeno vrijeme $(32,70 \%)$. Iz grafikona o općim podacima ispitanika možemo zaključiti kako najveći broj ispitanika ima srednju stručnu spremu $(84,00 \%), 10-15$ godina radnog staža $(39,50 \%)$ te ugovor o radu sklopljen sa poslodavcem na određeno radno vrijeme $(67,30 \%)$. 
IVICA ČREPINKO, DINKO PRIMORAC, GORAN KOZINA: Analiza poslovnih problema malih...

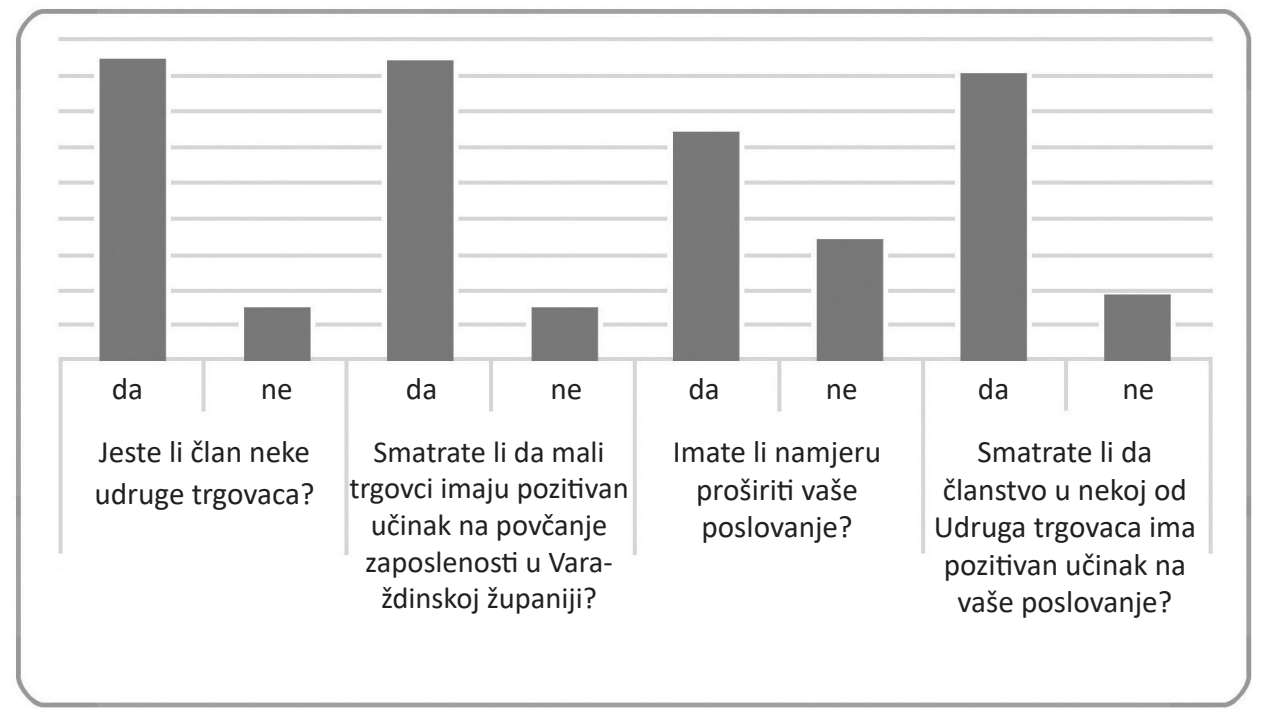

Grafikon 3. Podaci o subjektivnom razmišljanju ispitanika/prednosti, Izvor: istraživanje autora rada

Prema rezultatima istraživanja veliki broj ispitanika je član neke od udruge trgovaca $(84,80 \%)$, manji dio ispitanika nije član ni jedne udruge trgovaca $(15,20 \%)$. Također veliki dio trgovaca smatra da imaju pozitivan učinak na povećanje zaposlenosti u Varaždinskoj županiji (84,30\%), a tek manji broj ispitanika smatra da nemaju pozitivan učinak na povećanje zaposlenosti u Varaždinskoj županiji $(15,70 \%)$. Rezultati istraživanja pokazuju kako veći broj ispitanika ima namjeru proširi poslovanje (64,90\%), a manji broj ispitanika nema namjeru proširiti poslovanje $(35,10 \%)$, nadalje provedeno istraživanje pokazuje kako veliki broj ispitanika smatra da članstvo u nekoj od udruga ima pozitivan učinak na njihovo poslovanje (81,20\%), a tek manji dio ispitanika smatra da članstvo u nekoj od udruga trgovaca nema pozitivan učinak na njihovo poslovanje $(18,80 \%)$. 


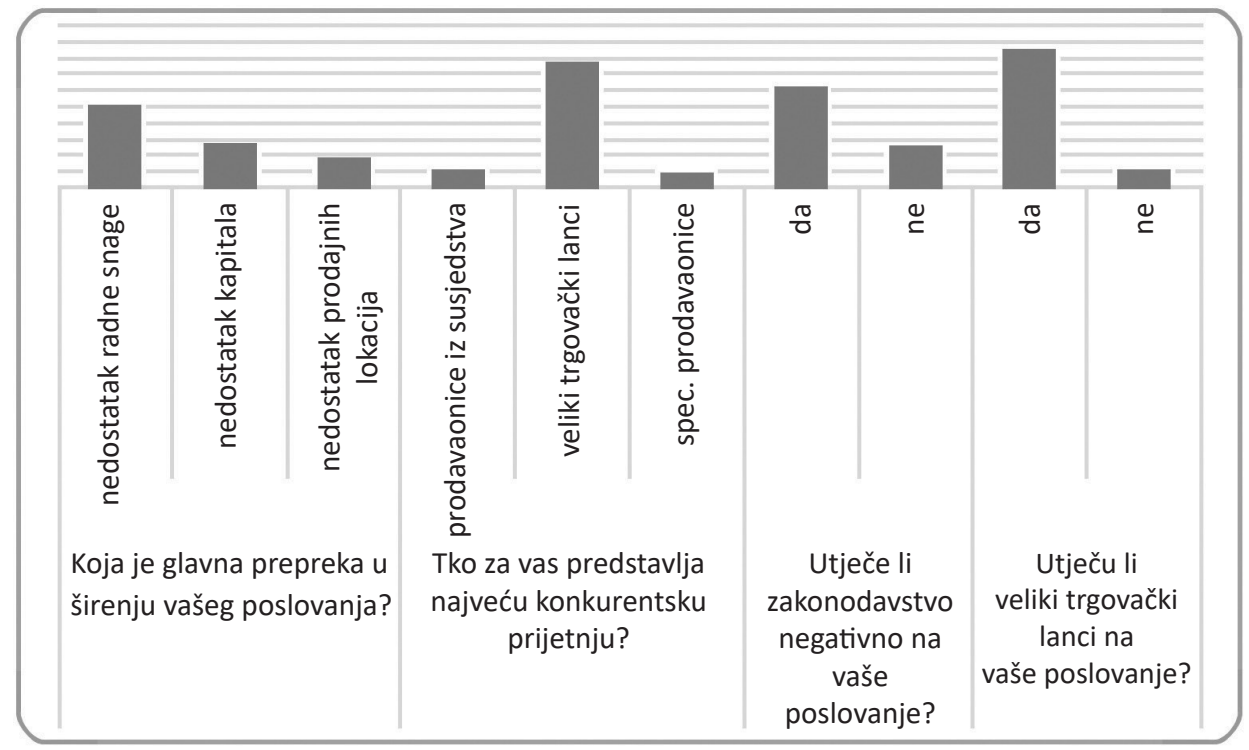

Grafikon 4. Podaci o ograničenjima ispitanika, Izvor: istraživanje autora rada

Iz grafikona o subjektivnom razmišljanju ispitanika vidljivo je da najveći broj ispitanika smatra kako je glavna prednost članstvo u udrugama $(84,80 \%)$, pozitivno utječu na zapošljavanje u Varaždinskoj županiji (84,30\%), imaju namjeru proširiti svoje poslovanje (64,90\%), te smatraju da članstvo u nekoj od udruga trgovaca ima pozitivan učinak na njihovo poslovanje (81,20\%). Rezultati istraživanja pokazuju kako najveći broj ispitanika smatra najvećom konkurentskom prijetnjom velike trgovačke lance $(78,40 \%)$, zatim male prodavaonice i susjedstva $(11,50 \%)$ te skoro podjednaki broj ispitanika smatra konkurentskom prijetnjom i specijalizirane prodavaonice (11,10\%). Iz Grafikona 4 je vidljivo da veliki broj ispitanika kao prepreku u širenju poslovanja vidi u nedostatku radne snage $(51,40 \%)$, manji broj ispitanika vidi prepreku u nedostatku kapitala $(28,30 \%)$ te najmanji broj ispitanika vidi glavnu prepreku u širenju poslovanja u nedostatku prodajnih lokacija (20,30\%). Prema rezultatima provedenog istraživanja veći dio ispitanika smatra da veliki trgovački lanci utječu na njihovo poslovanje $(87,30 \%)$, a manji dio ispitanika smatra da veliki trgovački lanci ne utječu na njihovo poslovanje (12,70\%). Iz istraživanja je također vidljivo da veći broj ispitanika smatra da zakonodavstvo negativno utječe na njihovo poslovanje $(63,00 \%)$ te manji broj ispitanika smatra kako zakonodavstvo ne 
utječe negativno na njihovo poslovanje $(27,00 \%)$. Prema grafikonu o subjektivnom razmišljanju ispitanika možemo zaključiti da su glavna ograničenja u poslovanju ispitanika snaga velikih trgovačkih lanaca $(78,40 \%)$, nedostatak radne snage $(51,40 \%)$, utjecaj konkurentnosti velikih trgovačkih lanaca $(87,30 \%)$ i trenutno zakonodavstvo $(63,00 \%)$.

\section{ZAKLJUČAK}

U trenutno zahtjevnom i vrlo dinamičnom poslovnom okruženju mali i neovisni trgovci pronalaze razne načine za preživljavanje pa nerijetko i širenje svojih maloprodajnih objekata. Osnovni problemi sa kojima se susreću ne razlikuju se uvelike od ostalih maloprodajnih lanaca i velikih trgovačkih društava. Pritisak konkurencije i stranog kapitala dugoročno mijenja maloprodajno tržište u Republici hrvatskoj pa jednako tako i u Varaždinskoj županiji. Geografsko područje Varaždinske županije zadržalo je najveći broj malih neovisnih trgovaca u hrvatskoj, ali za razliku od ostalih područja mali trgovci u varaždinskoj županiji nalaze se isključivu u ruralnim sredinama. Na području grada Varaždina ne postoji više ni jedan mali neovisni trgovac, odnosno nestali su klasični „mali kvartovski dućani“. lako u manjem broju mali neovisni trgovci pozicionirani su u ruralnim sredinama u kojima raznim prednostima uspješno prkose pritisku konkurencije, udružili su se Udruge trgovaca koje njim omogućuju bolje nabavne uvjete kao bi se lakše borili sa konkurencijom. Unutar spomenutih Udruga trgovaca pronalaze i razne pravne informacije, dijele iskustva, savjete, informacije o kanalima nabave robe i aktivno prate konkurenciju. Sa svojim kupcima stvorili su dugoročan odnos povjerenja i bliskosti, asortimanom su prilagodili svoje maloprodajne objekte na optimalan broj artikala ponude i prodajnih kvadrata. Prilagodili su prodajne cijene skoro na razinu najvećih trgovačkih lanaca i optimizirali razinu troška poslovanja na najmanju moguću mjeru. Koliko je njihov model poslovanja i pristupa tržištu uspješan pokazuje i samo istraživanje, kapital za širenje poslovanja ne predstavlja najveći problem, već kao najveći problem poslovanja ističu zakonodavni okvir, te posebice nedostatak radne snage kao posljedice iseljavanja stanovništva u susjedne zemlje članice Europske Unije.

Varaždinska županija spada u gospodarski najrazvijeniji dio Hrvatske, ali zbog trenutne ekonomske krize, u vidu Covid pandemije, gospodarstvenici imaju poteškoće u svom poslovanju., Međutim, iz odgovora sudionika istraživanja vidljiv je model u kojem isti opstaju i šire svoje poslovanje. U trenutnoj pandemiji Covid virusa maloprodajni kupci sve više se okreću sigurnosti i traže povjerenje u vidu 
kupnje u susjedstvu i nerado odlaze u velike gužve i trgovačke centre. Ako usporedimo predstavljeno istraživanje s prethodnim znanstvenim istraživanjima u Republici Hrvatskoj možemo primijetiti određena odstupanja i nejednakosti. Naime, prethodna istraživanja u zadnjih deset godina pokazuju kako se potrošači okreću velikim trgovačkim centrima i prodajnim lancima kako bi što efikasnije iskoristili svoje vrijeme. Međutim, u današnjem turbulentnom vremenu potrošači se vraćaju starim navikama tj. malim i neovisnima trgovcima gdje se osjećaju sigurnije te bolje prihvaćeni. Mali i neovisni trgovci moraju iskoristiti ovakvu šansu te se postaviti kao odgovorni, dosljedni i „prijateljski“ orijentirani partneri prema svojim potrošačima. Slijedom svega gore navedenog moguće je zaključiti kako mali neovisni trgovci Varaždinske županije u budućnosti imaju sigurnu maloprodajnu poziciju uz siguran budući rast poslovnih aktivnosti. Svakako bi bilo poželjno napraviti slično istraživanje i u ostalim hrvatskim županijama kako bi se dobiveni podaci usporedili, te se prikazale sličnosti i različitosti između županija.

\section{LITERATURA}

1/ ANIĆ, I. D. (2021). "Sektorske analize: Trgovina na malo", Ekonomski institut Zagreb, Zagreb.

2/ BUTIGAN, N. (2017). "Strateški savezi u trgovini na malo u Europskoj Uniji i zemljama Središnje i Istočne Europe", Ekonomska misao i praksa, No. 2.

3/ ČREPINKO, I., "Utjecaj malih neovisnih trgovaca na razvoj gospodarstva Sjeverozapadne Hrvatske", (2020). Libertas međunarodno sveučilište, Zagreb.

4/ HUŠKA, D. (2017). "Utjecaj globalizacije na području trgovine na malo u Hrvatskoj 1997-2016.", Zbornik sveučilišta Libertas, Vol. 1 - 2 No. 1 - 2.

5/ KNEGO, N., PETLAK, K., VOUK, R. (2014). "Location and layout as sources of competitive advantage of small retailers", Economy \& Business Journal, International Scientific Publications, Bulgaria, vol. 8 (1).

6/ Perkov, D. (2010). "Hrvatski mali trgovci danas-sutra", Progressive Magazin 2.

7/ Segetlija, Z., Lamza-Maronić, M. (1999). Strategija maloprodaje. Sveučilište Josipa Jurja Strossmayera u Osijeku, Osijek.

8/ Škrtić, M., Primorac D., Mikić, M., (2015) "Od ideje do realizacije poduzetničkog projekta", Sveučilište Sjever, Varaždin.

9/ Hrvatski zavod za zapošljavanje, www.hzz.hr (18. 08. 2020.).

10/ Hrvatski zavod za statistiku, www.dzs.hr (19. 08. 2020.). 
11/ Hrvatska gospodarska komora, www.hgk.hr/zupanijska-komora-varazdin (15. 06. 2020.).

12/ Udruga malih trgovaca Međimurje, www.jatrgovac.com/tag/udruga-trgovaca-medimurja, (18. 06. 2020.).

13/ Ekonomski institut Zagreb, www.eiz.hr, (16. 06. 2020.).

\section{SUMMARY}

\section{ANALYSIS OF BUSINESS PROBLEMS OF SMALL AND INDEPENDENT TRADERS IN VARAŽDIN COUNTY}

This paper analysis a business problems of small and independent traders e.g. their impact on the development of the economy in northwestern Croatia; especially Varaždin County. Since small and independent traders are extremely important for the trade in northwestern Croatia, this paper aims to show their impact on certain factors in the economy and to synthesize the basic problems that affect their development. Through empirical research the paper identifies the strengths and weaknesses of independent traders. Through the analysis in the research this paper contributes to a better understanding of the business of small and independent retailers, moreover the importance of the need for their good positioning in the market, and better connections with regular and potential consumers.

Key Words: retail; Varazdin county; small independent traders. 